\title{
Turkey's Relations With the Central Asian Countries and Europen Union
}

\author{
Sadık Ridvan Karluk \\ Turgut Ozal University, Ankara, Turkey \\ Sevilay Küçüksakarya \\ Anadolu University, Eskisehir, Turkey
}

The purpose of this paper, in the light of recent developments, is to analyze whether or not there is an axial drift in Turkey, which is a part of Europe. With the decision of the Parliament of the Federal Republic of Germany, after the collapse of the wall, known as the iron curtain, built on August 13, 1961 in Berlin, the Soviet Union disintegrated on the date of December 25, 1991 and a new unipolar restructure came into view. New hopes, uncertainties, and new threats were brought along by the US-led restructuring. The Cold War period ended, a drastic change process with the Eurasian axis in the international relations started to be lived in, and the world order based on the the nuclear balance between the East and the West also died out. Having been located at the intersection point of Europe and Asia and therefore of strategic importance, Central Asia has been bringing together the two continents for centuries. In this geography, Turkey has been the first country to recognize the Republics that have gained their independence for the last 20 years. Starting in 1991, the relations between Turkey and Central Asia countries progressed swiftly. Turkey, on one hand, has been developing the economical and political relations with the aforesaid countries, but on the other hand, it has also been continuing to progress on the course of being granted a full membership to the EU (European Union). Turkey has been the only Muslim country to head towards the West since Tanzimat (the Reformations in 1839). Besides, Turkey, by having preserved the cultural values, having adopted the democratic principles, having a common border with the Western world, and being her neighbour, is the only and the most developed country to have chosen the West on the economic, cultural, social, and sporting areas among the 57 Islamic countries existing in the world. Turkey, with different political and economic systems, is ready to contribute towards ensuring peace and economic prosperity in Central Asia and Eurasia. The diplomatic activity demonstrated by Turkey in its region was interpreted by some parties as undergoing a shift in the axis of the country and becoming Islamized. The development preparing the ground for the emergence of the axis debates in Turkey is that the relationship between Turkey and EU has come to a dead end. While about $80 \%$ of the public supporting for full membership in the years of 1999-2005, this proportion dropped to $40 \%$ in recent years. Without the support of the public opinion, no government in the Republic of Turkey will be enthusiastic about the EU membership, as it is, the relations between Turkey and the Western world will decline

Sadık Ridvan Karluk, professor, Faculty of Economics and Administrative Sciences, Department of Economics, Turgut Ozal University, Ankara, Turkey.

Sevilay Küçüksakarya, Ph.D., assistant professor, Faculty of Economics and Administrative Sciences, Department of Economics, Anadolu University, Eskisehir, Turkey.

Correspondence concerning this article should be addressed to Sadık Ridvan Karluk, Turgut Ozal University, Department of Economics, Faculty of Economics and Administrative Sciences, 06010 Ankara, Turkey. E-mail: rkarluk@turgutozal.edu.tr. 
and the axis shift in Turkey will perhaps become a fact in this case. For this reason, an initiative, called Positive Agenda, was launched for the purpose of not breaking off the relations and preventing Turkey from setting sail for new shores. This new approach is not targeting to replace but to complete the accession process, and the development of the more constructive and positive relationship between EU and Turkey is targeted as well. The world's economic axis will shift from the West to the East in the next 50 years. The harsh criticism of the double standards of the West voiced by Turkey in the non-Western regions, such as the Middle East, the Balkans, and the Caucasus, is causing to be perceived by the Western world as Turkey is not a partner but a competitive power and the close relationship with the groups and the actors against the West in the Middle East is leading to interrogate about what kind of partner it will be in Europe. When NATO (North Atlantic Treaty Organization) was formed 63 years ago, the collapse of the Soviet Union in 1989, that the Central Asia countries would gain their independence, that two-block structure of Europe would disappear, and that the Warsaw Pact would disband, could not be predicted by any one. Axis is shifting from the West to the East. By realizing this fact, Turkey has to determine a new strategy. As a result, in this statement, the position of Turkey, which is a part of Asia and Europe, against the latest development in the region, will be analyzed.

Keywords: Central Asian countries, Turkey, Europe, EU, Cold War, independence

\section{Introduction}

After the destruction of the wall on November 9, 1989, also known as "iron curtain", which was built in Berlin on August 13, 1961 with the verdict of the East Germany Parliament, Union of Soviet Socialist Republics was dispersed on December 25, 1991. As a result of this, the cold war era came to an end and a rooted change process with the Eurasian axis was started to be experienced in the international affairs. The world order based on the nuclear balance between the East and the West became a part of the history.

The new unipolar construction under the leadership of the USA has brought along with the new hopes, ambivalence, and new threats. In this context, being in the continent of Europe, the new political institutions started to be created in the continent of Asia as well, the collaboration among the sates has increased, and the South Korea became a member of the Organization for Economic Corporation and Development in 1996 which is the most important international organization of the West.

Located in a place where Asia and Europe intersect, thus having a strategic importance, Central Asia has been bringing the two continents together for hundreds of years. Turkey was the first country to recognise the countries that had gained their independence in this geography, after dispersion of the Union of Soviet Socialist Republics. Beginning from the year of 1991, the relationship between Turkey and the Central Asian countries has developed swiftly and the embassies have been opened by Turkey in all of the Central Asian Republics.

While the relationship between Turkey and the Central Asian countries was developing, Turkey's ties with the Euoropean Union have been far from linear. The accession negotiations with EU, starting from October 3, 2005, could not be moved ahead; out of 35 chapters, 14 chapters were opened, only one of them was closed temporarily, the 12 chapters was freezed by the Greek Cypriot Administration of Southern Cyprus, and France has nearly quenched the accession hope of Turkey.

In this paper, whether the increasingly devoloping relationship between Turkey and Central Asia, together with its countries, will be an alternative to the EU (European Union), will be discussed. 


\section{Turkey and the New Geopolitics of Central Asia}

The economic and political relationship between Turkey and the Central Asian countries, having gained their independence, is developing after dispersion of the Union of Soviet Socialist Republics. Now, besides Turkey, there are other sovereign states in which Turks are the dominant political group, in which a related language is officially spoken, and the culture of which has much in common with that of Anatolia. In the continent of Europe, as well as in Central Asia, the new economic and political organisations and the relationship among the countries in the region were created and started to be developed in the different institutions.

Commonwealth of Independent States (CIS) was the most important one among them. Founded with the Treaty of Minsk on December 8, 1991 among Belarus, Russian Federation, and Ukraine, CIS is a regional organization, whose participating countries are former Soviet Republics and which is formed during the break-up of the Soviet Union. Apart from the Baltic States, all of the former Soviet Republics took side of the treaty. Until 1993, Azerbaijan parliament had not ratified the treaty. At the end of 2010, the member states of the CIS signed the Free Trade Agreement.

The members of the CIS are Belarus, Armenia, Kazakhstan, Kyrgyzstan, Moldova, Uzbekistan, Ukraine, Turkmenistan, Tajikistan, and the Russian Federation. Turkmenistan passed into a status of partner membership. Georgia separated from the CIS on August 17, 2009. CIS, with its population of 284 million, is among the largest markets of the world. It covers an area of 22 million $\mathrm{km}^{2}$.

Another economic collaboration initiative in the Eurasian geography is the Common Economic Zone. The Free Trade Agreement was signed among Ukraine, Belarus, Kazakhstan, and Russian Federation on September 19, 2003. The agreement was ratified on September 20, 2004. Ukraine ratified the agreement on condition that the agreement must be compatible with its constitutions. The establishment of the free trade zones, lifting the restrictions on the commerce of the goods and services, the implementation of the common custom, and commerce policies were aimed.

The establisment process of the Eurasian Economic Community (EurAsEC) started with the agreement of the Customs Union signed by Russian Federation and Belarus on January 6, 1995. It was founded with the agreement signed by Belarus, Kazakhstan, Kyrgyzstan, Russia, and Tajikistan on October 10, 2000. Moldova and Ukraine in 2002 and Armenia in 2003 participated in the organization as observers. On October 7, 2005, it was decided among the member states that Uzbekistan would join on January 25, 2006. Uzbekistan became a member of the EurAsEC. A Common Economic Space for the EurAsEC was launched on January 1, 2010. The EurAsEC has been granted the status of observer in the General Assembly of the United Nations.

Economic Cooperation Organization (ECO) is another important organization, which was founded by Turkey, Iran, and Pakistan in 1985, for the purpose of promoting economic, technical, and cultural cooperation among the member states. It was the successor organization of what was the Regional Cooperation for Development, which ended activities in 1979. The Presidents and Prime Ministers of Turkey, Iran, and Pakistan published a declaration in order to improve a Regional Cooperation in 1964 and thus the Regional Cooperation for Development Organization was founded. In the fall of 1992, the ECO expanded to include seven Central Asian countries, namely Afghanistan, Azerbaijan, Kazakhstan, Kyrgyzstan, Tajikistan, Turkmenistan, and Uzbekistan.

After the dispersion of the Union of Soviet Socialist Republics, Azerbaijan, Kazakhstan, Kyrgyzstan, Tajikstan, and Turkmenistan, which had gained their independence, along with the participation of Afganistan, 
it has been a regional organization with an economic gravity that addresses an approximate population of 400 million on a total area of 7 million $\mathrm{km}^{2}$. It has been assessed as a powerful mechanism for the economic stability and improving the mutual collaboration among the member states of the ECO.

Another important organization is Shanghai Cooperation Organization in the region of Eurasia. It was founded by People's Republic of China, Kazakhstan, Kyrgyzstan, Russia, Tajikstan, and Uzbekistan on April 14, 2001. Its name comes from the place, Shangai, where the first meeting was held. Except for Uzbekistan, the other countries had been members of the Shanghai Five, founded in 1996; after the inclusion of Uzbekistan in 2001, the members renamed the organization.

India, Iran, Mongolia, Pakistan, and Afghanistan have the status of observers and Belarus, Srilanka, and Turkey have the status of "dialogue partner". Its six full members account for $60 \%$ of the land mass of Eurasia and its population is a quarter of the world's. With observer states included, its affiliates account for half of the human race.

Turkey, having applied for the status of dialogue partner in 2011, was accepted as the dialogue partner to the organization in the 12th meeting of the President Council which was held in Beijing on June 7, 2012. Therefore, Turkey will undertake a more effective role in the international platform.

Putin, then President of Russian Federation, by saying that one polar world cannot be accepted, gave a clue of the organization mission in the Bishkek Summit of the organization in August 2007 (Fedynsky, 2007). Besides the military and political mission, the member states signed a frame agreement for the purpose of expanding the economic collaboration and aiming at creating a Free Trade Zone in the long term.

The member states of the organization are equivalent to three fifths of the continent of Asia. The organization, with a population of 1.455 million, constitutes one fourth of the world population, as the largest one of Eurasia with regard to economy and security (Peyrouse, 2007).

Erdogan, the Prime Minister of Turkey, at the press conference held after the Turkey-Russia High Level Cooperation Council Meeting on November 22, 2013 in St. Petersburg, by reproaching the EU and saying that "Take us into the Shanghai Cooperation Organization" made a suggestion to the Russian President Putin (Retrieved from http://www.hurriyetdailynews.com/turkish-pm-erdogan-to-putin-take-us-to-shanghai.aspx?pageID=238\&nID= 58348\&NewsCatID=359).

At the press conference held after the meeting, the Russian President, Vladimir Putin, by assessing the problem regarding Ukraine's suspension of the partnership agreement with the EU, said that they wanted to benefit from the Turkey's experience related to the EU (Retrieved from http://en.kremlin.ru/events/president/transcripts/19677).

Describing the experience of Turkey on these issues, the Prime Minister Erdogan replied to Putin,

That is very right, Turkey has an experience of 50 years. It is not easy. In reply to the assessment of Dear President, I am saying with another assessment, Take Turkey into the Shanghai Cooperation Organization. Get us out of this distress. (Retrieved from http://en.kremlin.ru/events/president/transcripts/19677)

In reply to the proposal of Erdogan, Putin said: "I certainly want to state that we will keep on cooperating on the effective works regarding the independent foreing policy" and Erdogan said: "I stated to Mr. Putin about our membership request for Shanghai and we consider this important" (Retrieved from http://en.kremlin.ru/events/president/transcripts/19677). 
Even if Turkey's request for being a member of the SCO was stated by the Prime Minister Erdogan himself, on no account can this membership be an alternative to the relationship between Turkey and the West.

\section{Turkey's Relations With the Central Asian Countries}

Central Asia is a strategically important region for ensuring the security and stability of the Euro-Atlantic region. Its energy resources are vital for global energy security and it is a major hub for gas and oil pipelines as well as trade corridors. Turkey is the first country to have recognized the independence of the Central Asian countries. Turkey's relationship with the Central Asian countries started just after these states' independence.

It has been accepted by Turkey that the democracy, the superiority of law, and the steps to be taken for human rights in these states will make positive contributions to the processes of the integration with the international society, stability, and the safety.

In their almost 20 years of independence, the Central Asian countries have made substantial progress in many areas, particularly in solidifying their sovereignty, institutionalizing their state-building structures, and elevating their level of integration with the world (Dragneva \& Wolczuk, 2012).

Turkey also supports the Central Asian countries to keep on their existences, as independent, with economic and political stability, to have cooperation with their neighbouring countries and adopted the democratic values. The Strategic Partnership Agreement signed with Kazakhstan in 2009 is a good example of the close collaboration that is being carried out with the regional states.

The economic relationship with the Central Asian countries increased in the course of time, an important progress has been covered in the field of trade, transportation, and communication. The total credit amount has been given through Eximbank by Turkey to the regional countries which have exceeded 1 billion US dollars. In order to ensure to coordinate the aids for the Central Asian countries effectively, a cultural, economic, and technical cooperation agency, which is called as the Turkish International Cooperation and Development Agency (TIKA), was established in 1992.

The TIKA is a government department of the Prime Ministry of Turkey. TiKA is responsible for organization of the bulk of Turkey's official development assistance to developing countries and Central Asian countries.

The newly independent Central Asian countries were given necessary support to become members of such organization as the UN and Organization for Security and Co-operation in Europe (OSCE). A role, in order for these states to become associate partners of NATO's Partnership for Peace Programme, was assumed (Retrieved from http://www.nato.int/cps/en/natolive/topics_107957.htm). Turkey's approach is based on mutual acquisition and respect for their independence and territorial integrity.

In 1992, hosted by Turkey's President Turgut Ozal and with the participation of Azerbaijani President Ebulfazl Elchibey, Kazakhistan President Nursultan Nazarbayev, Kyrgyzstan President Askar Akayev, Uzbekistan President Islam Karimov, and Turkmenistan President Saparmurad Niyazov, a summit was carried out in Ankara and Ankara Declaration was signed.

At the summit, by harmonizing the customs legislation between Republic of Turkey and the countries in the region, a free trade arrangement to establish the free circulation, a joint investment, and development bank, improve railways, highways, airways connections, and communication potentials, and the transportation of the natural resources to Europe via Turkey were the issues to be focused on. 
In order to create the new cooperation opportunities and increase solidarity among the Turkish speaking countries, Turkey has been leading Turkish Speaking Countries Heads of State Summit Processes which have been held since 1992. This process was converted to a corporate structure with the Nakhchivan Agreement, which was signed on October 3, 2009, on the establishment of Turkish Speaking Countries Cooperation Council. A council was decided to be set up at the 10th Summit held in Istanbul, September 2010. The Council's secretariat is located in Istanbul.

The 11th summit, hosted by the Republic of Kazakhstan President, Nursultan Nazarbayev in Almaty, was carried out between October 20 to 21 in 2011. The Almaty summit, having the characteristic of the first Summit under the corporate frame of the Turkish Council, was also the first summit which has been collected under the one topic at the same time. Economic Cooperation was dealt with in this contex.

Turkey, since the independence obtainment of the Central Asian countries, has made substantial efforts in order for countries to establish bilateral and multilateral relations with the international community. Turkey believes that the Central Asian countries' participation in the Euro-Atlantic institutions will make a major contribution to ensuring peace and stability in Eurasia (Karluk, 2008).

Even if the economic and political relations between Turkey and Central Asian countries have gained strength in the course of time, the request to become a member of the SCO has been pronounced by Prime Minister Erdogan. This situation does not mean that Turkey will turn its back to the EU. Growing economic and political relation with the countries of Central Asia is not an alternative to the EU.

Turkey, with different political and economic systems in this region, both Asian and European, is ready to contribute to peace and the establishment of economic prosperity as a literally Eurasian country (Karluk, 2014a).

\section{Turkey Relations With the EU}

After Greece, in 1959, Turkey was the second European country to apply to the then European Economic Community for associate membership. Turkey's application to accede to the European Economic Community, a predecessor of the EU, was made on April 14, 1987. Turkey has been an associate member since 1963 (Karluk, 2013).

During this time, the number of the members of the EU has reached from six up to 28 . There come Balkan countries, Iceland, and including Serbia as well. There has been 54 years, since Turkey's application for membership to EU, 26 years since the application for full membership, 17 years since the realization of the customs union, 14 years since the acquisition of the candidate status, and eight years since the start of the negotiations.

In line with the decision taken by the EU States on December 17, 2004 summit, Turkey began EU accession negotiations on October 3, 2005. When the decision was taken in the 2004 summit, the EU recommendation specifying that the Copenhagen political criteria has been sufficiently met was taken into account and Turkey's EU membership process has entered its final phase. The screening process started on October 20, 2005 and was completed on October 13, 2006 impeccably and the determined schedule has been adhered to.

\section{Turkey's Commitments Regarding the Additional Protocol}

Turkey has been the only Muslim country that has directed to the West since Tanzimat (the reorganization 
made in the Ottoman State in 1839). In addition, Turkey, having adopted secular and democratic principles, having a common border with the West, and having a historical relationship with the EU countries, is the most developed country in the economic, political, social, and cultural fields among the 57 Islamic countries. While preserving their cultural values, it has chosen the West as a life style.

How the countries perceive each other in international economic and political relations is very important (Karluk, 2014b). This perception has come into being through the mutual influence of the historical image and cultural background of the parts. In today's global world, perceptions can change rapidly. Just as the actions of the parts bring about the perceptions, the perception can chage when the action changes. If one does not know to which port one is sailing, no wind is favorable, Annaeus Lucius Seneca (Retrieved from https://en.wikiquote. org/wiki/Seneca_the_Younger). Turkey has been struggling to catch this wind for almost two centuries.

Carried out in accordance with the Additional Protocol and the Ankara Agreement, the Customs Union, beyond being a purely economic integration model, has been an important stage towards the integration goal of Turkey with the EU. The partnership's ultimate goal was the Turkey's membership in the article 28 of the Ankara Agreement (Karluk, 2013).

Turkey, in the expression of the eighth President Turgut Ozal, has been struggling to fulfill their obligations in the hope of becoming the EU member on "a long and thin road" by turning a blind eye to the EU's double standards. Accession negotiations, in the expression of the Foreign Minister, Davutoglu, will have been completed by 2023. It is widely accepted that Turkey will not become an EU member at its 100th foundation anniversary (Wimmel, 2006).

No candidate countries should be waited in front of the EU door in the enlargement process. On December 17, 2004, the decision taken by the Heads of States and EU Government is: If Turkey would not become an EU member, the question is that Turkey would be fully anchored in the EU institutions. Spud (anchoring) means: If you are not going to become an EU member, do not sail away. Turkey can not accept this situation.

German Chancellor, Angela Merkel, proposed to establish a priviliged partnership, which has a narrower scope than the full membership, between Turkey and the EU, and has not made a statement relating to the content though (Retrieved from http://www.eubusiness.com/news-eu/turkey-germany.3st). Merke insisted that a non-statutory privileged partnership as regards the EU legislation should be a great misfortune. Merkel's statement "We need to continue to the open-ended negotiation process" is also contrary to EU law (Retrieved from http://www.turkishnews.com/en/content/tag/merkel/).

Within the scope of the EU's European Neighbourhood Policy, privileged partnership may apply to such countries as Israel and Ukraine. Although privileged partnership has not been formally defined in EU legislation, theoretically privileged partnership is a model of a relationship, guaranteeing the free movement of goods, capital, and services among the EU countries, which is on the basis of the common market.

Due to the pressure put by EU on Turkey about Cyprus, privileged partnership insistently proposed to Turkey, TUAFU ${ }^{1}$ criteria implemented against Turkey, and Europe does not want to get Turkey into itself. Even so, the Europeans accepted Turkey as a European state in 1856, but it has taken Turkey into the scope of AFU and started to practice double standards (Alessandri \& Onar, 2012).

That Turkey's candidacy for the EU has been emerged as a controversial subject and leading to division in society has brought the relationship to the point of break in terms of both EU and Turkey. American think-tank

${ }^{1}$ TU: Those of US - 22 Christian countries joining the EU after the six founder countries; AFU: Apart from US-Muslim Turkey. 
institution - the German Marshall Fund, makes large-scale public opinion survey in 12 countries each year.

USA, EU member states, and Turkey were taken part in 2013 Transatlantic Trends survey. EU member countries are: France, Germany, Italy, Netherlands, Poland, Portugal, Romania, Slovakia, Spain, Sweden, and the United Kingdom. The research was performed with the German Marshall Fund of the United States, the Compagnia di San Paolo, the Barrow Cadbury Trust, Fundação Luso-Americana, the BBVA Foundation, the Communitas Foundation, and the Swedish Ministry for Foreign Affairs.

The research was completed for all of the countries between June 3-27, 2013, and for Turkey on July 2, 2013. In the survey conducted for research, the method of face to face or telephone interviews with the citizens in these countries was used. According to the survey, the Turkish people's dream of becoming a member of the EU has finished.

According to the results of research conducted between June 2-27, 2012, only $38 \%$ of the Turks were of the opinion that EU membership is good. In the similar research conducted by Transatlantic Trends in 2004, the support of the Turkish people for EU membership was $73 \%$. In recent research, $20 \%$ of the participants from EU countries said that Turkey's accession to the EU would be positive, while $43 \%$ of the Turks would consider it bad. Thirty-seven percent of participants did not declare that either it would be bad or good.

In this case, the following assessment of the great leader Atatürk in 1923 turned out to be true,

Our enemies have instilled hatred and hostility among European nations against the Turks for centuries. These ideas located in western thought have created a special understanding. This mentality still exists. In Europe is still assumed that the Turks are the enemy of the progress and development. This is a great mistake. (Retrieved from http://www.dr.com.tr/kitap/avrupa-birligi/s-ridvan-karluk/arastirma-tarih/politika-arastirma/avrupa-birligi-turkiye/urunno= 0000000371852)

From time to time, the analogy of "the country running to east on a westward sailing ship" was also made, but it is not true proven by the European and Western military and political institutions of which Turkey is a member. No Muslim country except Turkey is the member of all European institutions apart from the European. Although these negative developments are in Turkey's relations with the EU, the shift in Turkey's axis towards Asia is likely to be very weak.

\section{Conclusions}

The EU does not want to embrace Turkey that is really great and has problems. Two great founder countries of the EU, Germany and France are leading the way in the creation of this decision.

In Germany, after the general elections held on September 22, 2013, the statement of "in case the EU can not accept a new member or Turkey can not fulfill its obligations, Turkey should be attached to the European structures in a way that empowers the priviliged relationship between Turkey, the EU and Germany" specified in the171-page draft coalition agreement which was prepared within the scope of the coalition negotiations that began between CDU/CSU and SPD, confirms the aforementioned judgement.

Even if the negotiation process of 35 chapters is completed by Turkey, EU membership is not guaranteed. First, Greek Cypriot Administration of Southern Cyprus and then France may veto Turkey's EU membership. In addition, the European Parliament may not approve Turkey's membership as well. Because there were four decisions of the European Parliament: First were adopted in 1987 and the others were adopted after then, regarding that Turkey can not become an EU member as long as they did not accept the quasi Armenian genocide in 1987 and after its first four decisions are adopted. 
However, Turkey's EU membership will contribute to both France and Germany. France and Germany, as powerful economies and the leading countries that founded the EU, beware of Turkey's potential to be the regional power. Moreover, Germany, when Turkey gets into the EU, will lose effectiveness in the ballots. In a survey conducted, it was shown that, in the case of Turkey's being an EU member, the greatest decline, by $17.62 \%$, in the voting power index, was for Germany. In other words, Turkey's joining the EU has adversely affected most of Germany.

Even if the target to be among the 10 largest economy in the world in 2023 seems to be a little pretentious, some studies predict that Turkey will be among the first 20-economy (12th largest economy) in the world in terms of economic size (GDP).

Turkey will not break away with the Western world to which turned its face, since the Treaty of Paris will continue to have the courage of their convictions for some time by tolerating the double standarts that are not applied to another country.

A budget for the period of 2014-2020 was planned without taking Turkey's membership into account, indicating that Europe does not see Turkey as a member in the years of 2014-2020. France and Germany have always had doubts about allowing a largely Muslim country of 76 million people into the European club, fearing that cultural differences and its size will make it too difficult to integrate.

That EU membership emerges as a subject that leads to the divisions between the member states and the citizens of the EU governments brings the relationships to the breaking point in terms of both Turkey and EU. Continuous questioning of Turkey's candidacy serves no purpose other than to reinforce prejudices about the EU in Turkey.

Despite the increasing development of Turkey's economic and political relations with the countries of Central Asia and the Prime Minister Erdogan's request to become a member of the SCO, Turkey's place is of the Western world. While there have been problems in relations with the EU, an eastward shift of axis in the near future is not the case now in Turkey. The delays have fuelled frustration in Turkey, where public support for EU membership has slumped.

However, for the reason that the double standards applied to Turkey, if the Turkish public support for EU drops further, some alternatives may arise in the future. Because, without public support, no government in the Republic of Turkey would be willing to be EU members, in this case the relations between Turkey and the Western world would decline and an axis shift in Turkey would probably be in this case.

\section{References}

Alessandri, E., \& Onar, N. (2012). Turkey's transformation and its future influence: A critical link. Retrieved from http://www.gmfus.org/wp content/blogs.dir/1/files_mf/1350600595Alessandri_Onar_TurkeysTransformation_Oct12.pdf

Dragneva, R., \& Wolczuk, K. (2012). Russia, the Eurasian Customs Union and the EU: Cooperation, stagnation or rivalry? Retrieved from http://www.chathamhouse.org/sites/files/chathamhouse/public/Research/Russia\%20and\%20Eurasia/0812bp_ dragnevawolczuk.pdf

Eubusiness. (2010). Merkel wants "privileged partnership" between Turkey, EU. Retrieved from $\mathrm{http}: / /$ www.eubusiness.com/news-eu/turkey-germany.3st

Fedynsky, P. (2007). Shanghai cooperation organization seeks to expand energy and security influence. Retrieved from http://www.51voa.com/VOA_Standard_English/VOA_Standard_13422.html

Hurriyet Daily News. (2015). Turkish PM Erdoğan to Putin: Take us to Shanghai. Retrieved from $\mathrm{http}$ :/www.hurriyetdailynews.com/turkish-pm-erdogan-to-putin-take-us-to-shanghai.aspx?pageID=238\&nID=58348\&News CatID $=359$ 
Karluk, S. R. (2008). Relations of EU with Central Asian countries in a globalizing world and its strategy towards the region. Retrieved from http://academy.anadolu.edu.tr/display.asp?kod=0\&acc=rkarluk

Karluk, S. R. (2013). Avrupa Birliği Türkiye İlişkileri (European Union Turkey's relations). Retrieved from http://www.idefix.com/kitap/avrupa-birligi-turkiye-iliskileri-bir-cikmaz-sokak-s-ridvan-karluk/tanim.asp?sid=BYSR1XM41 B5BTLJEZWDC

Karluk, S. R. (2014a). Avrupa Birliği (European Union) Beta Basım A.Ş. İstanbul. Retrieved from $\mathrm{http} / /$ www.dr.com.tr/kitap/avrupa-birligi/s-ridvan-karluk/arastirma-tarih/politika-arastirma/avrupa-birligi-turkiye/urunno $=00$ 00000371852

Karluk, S. R. (2014b). Bridging civilizations from Asia to Europe: The silk road. Chinese Business Review, 13(12), $730-739$.

North Atlantic Treaty Organization. (2014). NATO's relations with Central Asia. Retrieved from http://www.nato.int/cps/en/natolive/topics_107957.htm

Official Internet Resources of the President of Russia. (2013). News conference following a meeting of the high level Russian-Turkish Cooperation Council. Retrieved from http://en.kremlin.ru/events/president/transcripts/19677

Peyrouse, S. (2007). The economic aspects of the Chinese-Central Asia rapprochement. Retrieved from http://www.silkroadstudies.org/resources/pdf/SilkRoadPapers/0709China-Central_Asia.pdf

Seneca the Younger. (n.d.). Retrieved from https://en.wikiquote.org/wiki/Seneca_the_Younger

Turkishnews. (n.d.). Speaking to Turkish Daily Hurriyet, Chancellor Merkel was asked how long Turkey will have to wait to join the EU. Retrieved from http://www.turkishnews.com/en/content/tag/merkel/

Wimmel, A. (2006). Beyond the bosphorus? Comparing German, French and British discourses on Turkey's application to join the European Union. Retrieved from http://aei.pitt.edu/7423/1/pw_111.pdf 